\title{
Implementasi Metode Korelasi Silang Untuk Deteksi Friksi Statis Katup di Kalang Kontrol
}

\author{
Mas Aji Rizki Widjayanto*), Awang N.I. Wardana \& Widya Rosita \\ Jurusan Teknik Fisika Fakultas Teknik Universitas Gadjah Mada \\ JIn. Grafika 2 Yogyakarta 55281 INDONESIA \\ mas.aji.r.w@mail.ugm.ac.id*)
}

\begin{abstract}
Abstrak
Sistem kontrol dalam suatu industri proses merupakan hal yang vital untuk operasional suatu pabrik. Performa buruk dari suatu sistem kontrol akan memberikan dampak negatif bagi operasional suatu pabrik, seperti operasi dari sistem kontrol yang tidak efisien dan efektif. Salah satu dari penyebab buruknya kinerja tersebut adalah friksi statis pada katup. Beberapa metode untuk mendeteksi friksi statis pernah diperkenalkan antara lain pengolahan sinyal berdasarkan pencocokan grafis dan bentuk sinyal. Dalam makalah ini dilakukan implementasi dari metode deteksi friksi statis pada katup berdasarkan metode korelasi silang yang dirumuskan oleh Horch. Teknik ini dilakukan dengan mengkorelasisilangkan antara variabel proses dan keluaran pengendali dari suatu kalang kontrol. Dalam makalah ini disajikan hasil implementasi algoritma dengan dua jenis masukan, yaitu data simulasi dan implementasi dari industri amonia. Hasil dari penelitian ini menunjukkan bahwa metode korelasi silang dapat mendeteksi friksi statis dengan tepat pada data simulasi dan data industri amonia. Kebenaran dalam mendeteksi friksi statis pada katup ditunjukkan dari validasi terhadap data-data yang sudah diketahui kondisinya. Selain itu, metode dipilih karena kemudahan dalam implementasi sebagai kelebihan dari metode korelasi silang.

Kata Kunci: Sistem kontrol, friksi statis

katup,implementasi, korelasi silang.
\end{abstract}

\section{Pendahuluan}

Sistem kontrol dalam proses industri merupakan hal yang sangat vital untuk menjalankan operasi dari suatu pabrik. Jika kondisi sistem tidak berjalan sesuai dengan harapan akan memberikan hasil yang tidak optimal, seperti menurunnya kuantitas ataupun kualitas hasil industri [1]. Kondisi yang tidak optimal ini salah satunya disebabkan oleh ketidaklinieran. Beberapa penyebab ketidaklinieran antara lain friksi statis katup, wilayah mati, histeresis dan saturasi [2]. Namun, salah satu penyebab seringnya ketidaklinieran adalah friksi statis katup [3]. Friksi statis yang terjadi pada katup dapat menyebabkan perbedaan antara nilai masukan dan keluaran karena katup tidak dapat bergerak sesuai dengan keinginan yang diakibatkan gesekan statis yang besar melebihi gesekan dinamis sehingga dibutuhkan masukan yang lebih kuat hingga katup dapat bergerak.

Metode untuk mendeteksi buruknya performa pada kalang kontrol sudah banyak dilakukan. Pada awalnya beberapa permasalahan mengenai buruknya performa kalang kontrol diindikasikan oleh osilasi [1]. Beberapa metode untuk deteksi osilasi pernah dilakukan dengan metode regularitas dari titik temu nol oleh N.F. ThornhillI (2003), metode dekomposisi modus empiris yang dilakukan oleh Srinivasan dan Rengaswamy (2007). Metode berikutnya adalah integral absolut kesalahan pengendali yang diperkenalkan oleh Forsman dan Stattin (1999).

Kemudian penelitian mengenai buruknya performa berupa friksi statis pada katup diawali oleh Choudhury pada tahun 2005. Choudhury menjelaskan definisi-definisi friksi statis yang berhubungan dengan penyebab osilasi pada katup. Penelitian mengenai friksi statis pada katup pernah dilakukan menggunakan beberapa metode seperti metode pencocokan kurva yang dilakukan oleh Q. Peter He dan S. Joe Qin [5], kemudian juga terdapat penelitian yang didasarkan pencocokan relay yang dilakukan oleh Claudio Scali dan Muricio Rossi. Selain itu deteksi friksi statis katup pada katup juga pernah dilakukan dengan menggunakan metode pencocokan elips oleh Choudhury.

Metode berikutnya adalah metode korelasi silang yang diperkenalkan oleh Horch .Metode ini dilakukan dengan mengkorelasi silangkan antara data variabel proses (PV) dan keluaran pengendali (OP).

Sesuai dengan paparan, untuk mendeteksi performa sistem kontrol, di dalam makalah ini akan dijelaskan metode korelasi silang untuk pendeteksian friksi statis katup oleh Horch [2]. Selain itu makalah akan disajikan sebagai berikut: Bab 2 memberikan penjelasan mengenai metodologi penelitian yang digunakan. Metodologi penelitian ini terdiri dari penjelasan friksi statis pada katup. Bab 3 menunjukkan metode algoritma 
yang digunakan dalam pendeteksian friksi statis pada katup. Bab 4 memberikan hasil dari deteksi friksi statis katup menggunakan masukan data simulasi dan data industri. Sementara itu, pada bab 5 terdapat kesimpulan dari penelitian yang sudah dilakukan.

\section{Friksi Statis Katup}

Friksi statis pada katup ditandai dengan terjadinya gesekan statis yang lebih besar dari gesekan dinamisnya. Kondisi ini mengakibatkan bukaan katup tidak bisa mengikuti masukannya dengan tepat. Dengan demikian, untuk dapat menggerakkan katup dibutuhkan masukan yang lebih besar. Namun hal ini akan mengakibatkan lompatan pada katup sehingga gerakan yang ditimbulkan akan berlebihan. Friksi statis dapat direpresentasikan oleh dua parameter, yaitu S (wilayah mati ditambah lengket) dan J (lompatan). Friksi statis katup dan kedua parameter ini dapat dilihat pada Gambar. 1.

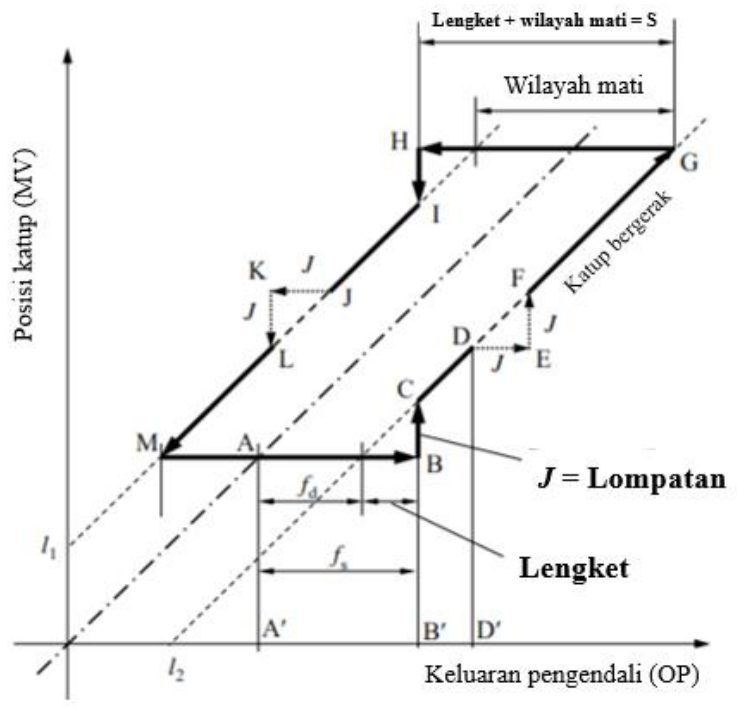

\section{Gambar 1 Grafik hubungan input-output katup kontrol karena friksi statis katup [3]}

Pada Gambar 1, titik A merupakan titik di mana katup akan mulai bergerak. Katup akan bergerak jika masukan katup memiliki nilai melebihi nilai gesekan statis (fs). Kemudian setelah katup diberikan masukan yang melebih nilai fs, maka katup akan bergerak ke posisi B dan meloncat ke posisi C. Selanjutnya katup akan bergerak perlahan menuju posisi D yang diakibatkan oleh gesekan kinetik saja. Karena pergerakan yang sangat lambat, kemungkinan katup akan mengalami lengket sampai titik $F$ dan katup akan bergerak kembali sampai titik G. Pada saat mencapai titik G, katup diberi masukan OP dengan arah yang berlawanan arah. Pada kondisi ini masukan OP harus melebihi nilai wilayah mati. Untuk mencapai titik I, maka harus diberi masukan OP sampai titik $\mathrm{H}$ hingga katup bergerak dan mengalami lompatan ke posisi I.

\section{Program Deteksi Friksi Statis Katup}

Untuk mendeteksi keberadaan friksi statis pada katup kontrol, langkah awal data harus terdeteksi osilasi. Dalam penelitian yang diacu oleh makalah ini, deteksi osilasi ini menggunakan integral absolut kesalahan pengendali yang dirumuskan oleh Forsman dan Stattin [6]. Kemudian untuk deteksi friksi statis digunakan metode korelasi silang yang dirumuskan oleh Horch [2]. Gambar 2 menunjukkan bagaimana diagram alir dari deteksi friksi statis pada katup yang terdiri dari 2 bagian yaitu integral absolut kesalahan dan deteksi friksi statis pada katup.

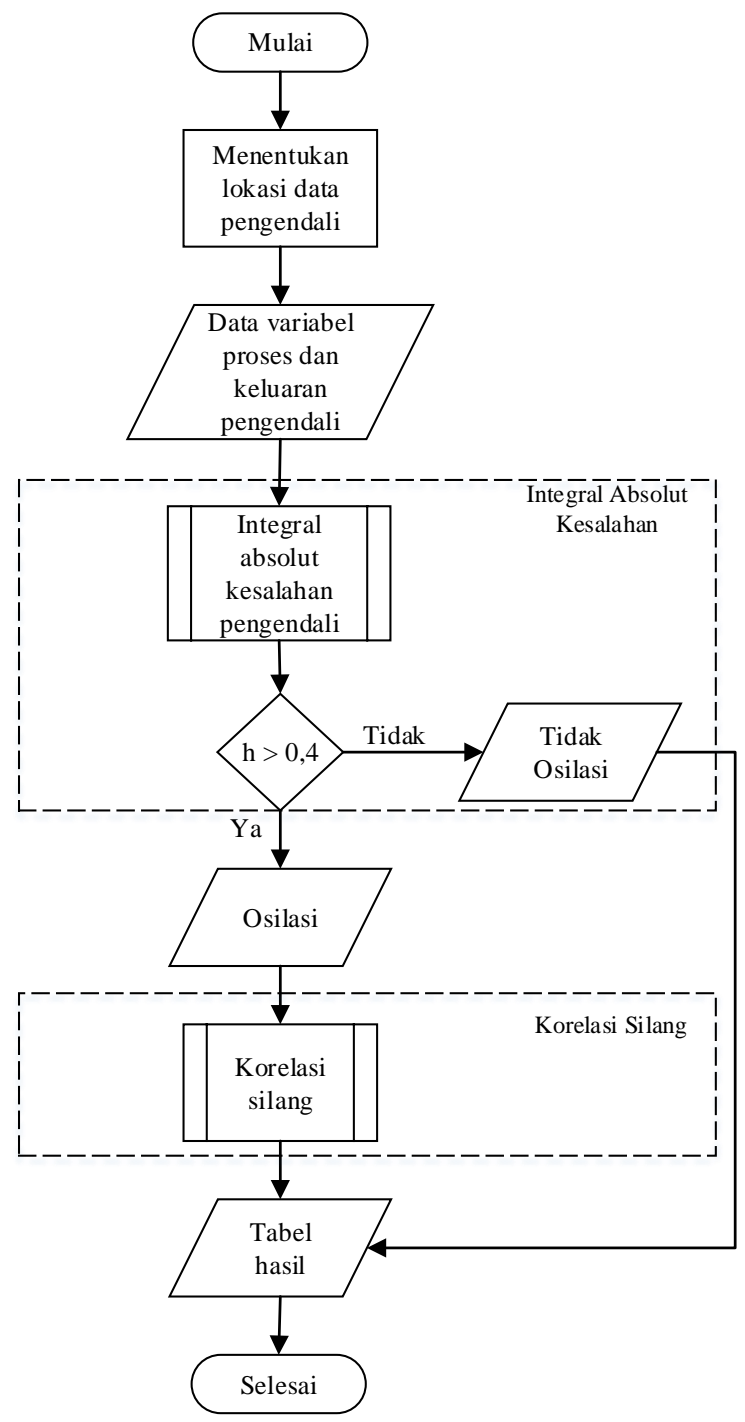

Gambar 2 Diagram alir program deteksi friksi statis pada katup [5] 


\subsection{Integral Absolut Kesalahan Pengendali}

Sebelum mendeteksi keberaan friksi statis katup, terlebih dahulu data harus terdeteksi osilasi. Parameter $h(N)$ merupakan indeks osilasi yang digunakan untuk menentukan suatu kalang kontrol mengalami osilasi. Jika $h(N)$ lebih dari dari batas yang ditentukan, maka data terdeteksi osilasi. Dalam penelitian yang diacu oleh makalah ini, digunakan batas 0,4 untuk $h(N)$ [1]. Nilai $h(N)$ bergantung terhadap dua elemen, yaitu waktu antar titik temu nol dan integral absolut kesalahan pengendali dari kesalahan pengendali (e) yang telah tapis oleh sebuah penapis frekuensi rendah. Kesalahan pengendali merupakan kesalahan pengendali yang didapatkan dari selisih antara data variabel proses (PV) dan rata-rata PV itu sendiri. variabel waktu antar titik temu nol $\left(\varepsilon_{n}\right.$ dan $\left.\delta_{n}\right)$ didapatkan dari perhitungan waktu antar titik temu nol pada interval positif dan negatif dari e. Sedangkan, integral absolut kesalahan ( $A_{n}$ dan $\left.B_{n}\right)$ didapatkan dengan menghitung integral absolut sinyal kesalahan pengendali pada interval positif dan negatif dengan rentang antar titik temu nol.

Untuk mendapatkan indikasi osilasi, parameter waktu antar titik temu nol dan integral absolut kesalahan harus dihitung cacah elemen yang masuk dalam kriteria osilasi atau tidak dengan persamaan 1 untuk interval positif dan persamaan 2 untuk interval negatif [1].

$h_{A}(N)=\#\left\{i<\frac{N}{2} ; \alpha<\frac{A_{i+1}}{A_{i}}<\frac{1}{\alpha} \wedge \gamma<\frac{\delta_{i+1}}{\delta_{i}}<\frac{1}{\gamma}\right\}$

$h_{B}(N)=\#\left\{i<\frac{N}{2} ; \alpha<\frac{B_{i+1}}{B_{i}}<\frac{1}{\alpha} \wedge \gamma<\frac{\varepsilon_{i+1}}{\varepsilon_{i}}<\frac{1}{\gamma}\right\}$

dengan nilai $\alpha=0,5$ dan $\gamma=0,7$ yang merupakan tingkat kesensitifan kriteria indikasi osilasi, sehingga bisa didapatkan indeks osilasi $h(N)$ pada persamaan 3 [1].

$$
h(N)=\left(h_{A}(N)+h_{B}(N)\right) / N
$$

dengan $h_{A}(N)$ dan $h_{B}(N)$ yang merupakan cacah elemen waktu antar titik temu nol dan integral absolut kesalahan yang masuk dalam kriteria pada persamaan 1 dan 2. Sedangkan, $N$ merupakan jumlah elemen integral absolut kesalahan yang terdapat pada sinyal kesalahan pengendali.

\subsection{Korelasi Silang}

Dalam deteksi friksi statis pada katup ini, digunakan metode korelasi silang yang dirumuskan oleh Horch [3]. Pada metode ini digunakan teknik korelasi silang. Teknik korelasi silang merupakan teknik korelasi antar nilai keluaran $y(t)$, dan nilai masukan $x(t)$. Secara umum, fungsi korelasi silang didefinisikan seperti pada persamaan 4 [1].

$$
r_{x y}(\tau)=E\{x(t+\tau) \cdot y(t)\}
$$

Metode korelasi silang untuk pendeteksian friksi statis katup dengan menghitung korelasi silang antara PV sebagai $y(t)$ dan OP sebagai $x(t)$. Indikasi friksi statis katup dengan metode korelasi silang bisa didapatkan dengan bentuk asimetris pada titik temu nol pertama sebelum dan sesudah titik tengah hasil korelasi silang [2]. Sedangkan, untuk indikasi tidak friksi statis katup didapatkan dengan bentuk simetris pada titik temu nol pertama sebelum dan sesudah titik tengah hasil korelasi silang [2]. Selain mengindikasikan friksi statis katup dengan cara tersebut, cara lain untuk mengindikasikan friksi statis katup pada metode ini bisa dilakukan dengan perhitungan dua variabel, yaitu parameter $\Delta \tau$ dan $\Delta \rho$. Kedua variabel tersebut merupakan representasi dari rasio pada sinyal hasil korelasi silang pada rentang titik temu nol pertama sesudah dan sebelum titik tengah hasil korelasi silang. Nilai $\Delta \tau$ dan $\Delta \rho$ dapat dihitung dengan persamaan 5 dan 6 [2].

$$
\Delta \tau=\frac{\left|\tau_{1}-\tau_{r}\right|}{\tau_{1}+\tau_{r}}
$$

Dengan $\tau_{r}$ adalah titik temu nol sesudah titik tengah hasil korelasi silang dan $\tau_{1}$ adalah titik temu nol sebelum titik tengah hasil korelasi silang.

$$
\Delta \rho=\frac{\left|r_{0}-r_{o p t}\right|}{r_{0}+r_{o p t}}
$$

Dengan $r_{0}$ adalah amplitudo pada titik tengah hasil korelasi silang dan $r_{o p t}$ adalah titik puncak sinyal hasil korelasi silang pada rentang titik temu nol pertama sebelum dan sesudah titik tengah korelasi silang. Gambar 3 menunjukkan ilustrasi rumus untuk menghitung variabel $\Delta \tau$ dan $\Delta \rho$.

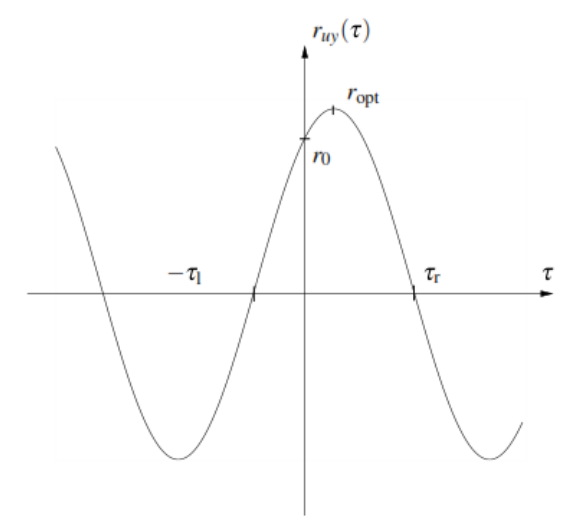

Gambar 3 llustrasi rumus untuk perhitungan $\Delta \tau$ dan $\Delta \rho$ 
Setelah perhitungan yang dilakukan dengan persamaan 5 dan 6 , maka bisa didapatkan hasil indikasi friksi statis katup dengan dimasukkan pada kriteria pada tabel 1.

Tabel 1 Indikasi friksi statis katup metode korelasi silang

\begin{tabular}{|c|c|c|}
\hline $0<\Delta \rho<0,072$ & Tidak friksi statis & $0<\Delta \tau<0,33$ \\
\hline $0,072<\Delta \rho<0,33$ & $\begin{array}{c}\text { Tidak ada } \\
\text { keputusan }\end{array}$ & $0,33<\Delta \tau<0,67$ \\
\hline $0,33<\Delta \rho<1$ & Friksi statis & $0,67<\Delta \tau<1$ \\
\hline
\end{tabular}

Setelah nilai kedua variabel tersebut dimasukkan ke dalam kriteria maka bisa didapatkan hasil indikasi friksi statis katup jika nilai $\Delta \tau$ melebihi 0,34 dan nilai $\Delta \rho$ jika melebihi 0,67 . Hasil kriteria yang termasuk dalam keadaan tidak ada pilihan menyatakan bahwa kondisi katup tidak berada pada kondisi friksi statis katup dan tidak friksi statis katup. Namun, hasil ini menyatakan kondisi ini disebabkan oleh kesalahan sensor atau pun elemen lain.

\section{Hasil dan Pembahasan}

Untuk mengetahui ketepatan hasil deteksi metode integral absolut kesalahan dan korelasi silang, metode ini akan digunakan untuk menganalisa data simulasi yang sudah diketahui hasilnya dan juga data berupa data industri. Data simulasi untuk deteksi osilasi terdiri dari dua yaitu osilasi dan tidak osilasi. Sedangkan data simulasi friksi statis katup terdiri dari dua bagian, yaitu data friksi statis katup dan tidak friksi statis katup.

Data untuk simulasi osilasi yang digunakan adalah data sinusoidal dan data sinusoidal yang tersamar dalam derau putih. Sedangkan, data tidak osilasi yang digunakan adalah data derau putih. Hasil dari simulasi dengan data osilasi dan tidak osilasi terdapat pada Tabel 2

Tabel 2. Hasil deteksi osilasi dengan metode integral absolut kesalahan pengendali

\begin{tabular}{|l|l|l|}
\hline \multicolumn{1}{|c|}{ Masukan } & $\begin{array}{c}\text { Indeks Osilasi } \\
h(N)\end{array}$ & Kesimpulan \\
\hline Sinusoidal & 0,897 & Osilasi \\
\hline Derau putih & 0,304 & Tidak Osilasi \\
\hline $\begin{array}{l}\text { Sinusoidal dalam } \\
\text { derau putih }\end{array}$ & 0,652 & Osilasi \\
\hline
\end{tabular}

Hasil deteksi osilasi dengan ketiga data tersebut ditunjukkan pada Gambar 4, Gambar 5, dan Gambar 6. Ketiga gambar ini menunjukkan
Kesalahan pengendali dari data sinusoidal yang digunakan untuk analisis osilasi.

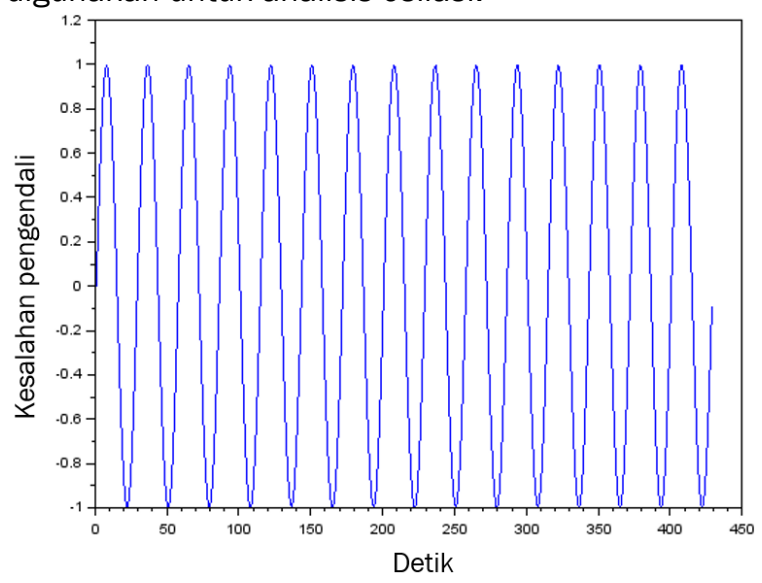

Gambar 4 Hasil metode integral absolut kesalahan pengendali dengan masukan sinusoidal

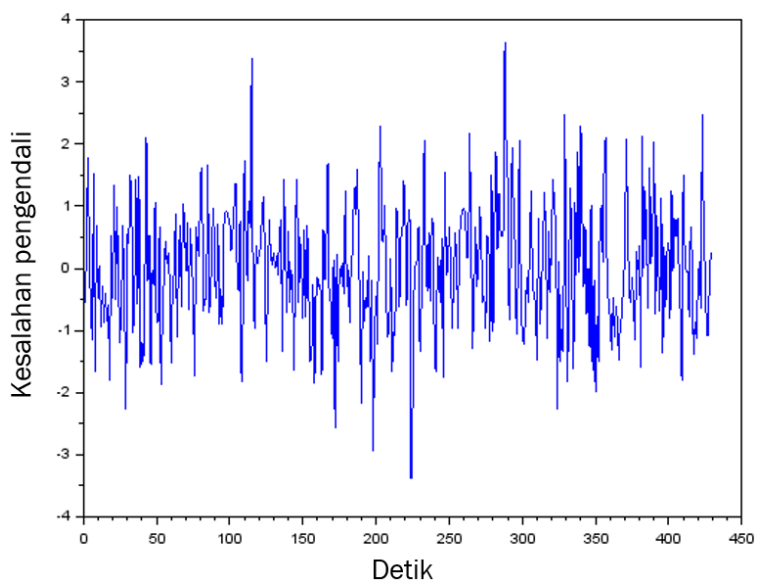

Gambar 5 Hasil metode integral absolut kesalahan pengendali dengan masukan derau putih

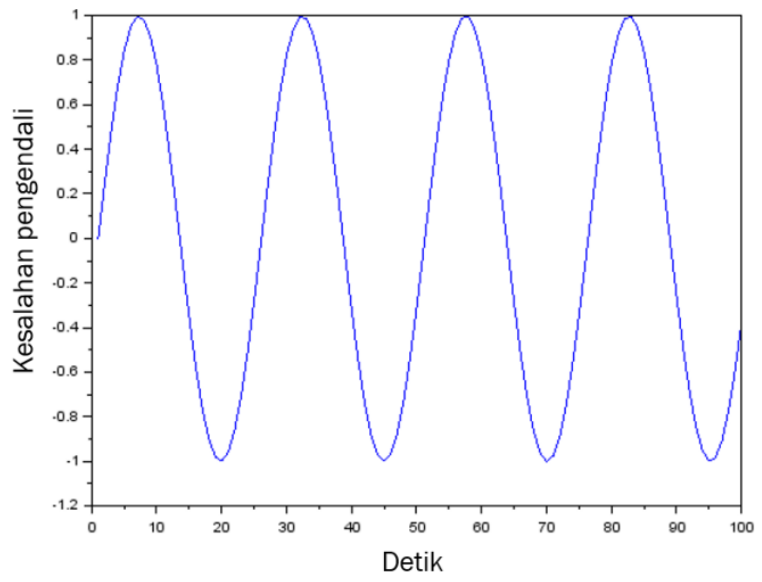

Gambar 6 Hasil metode integral absolut kesalahan pengendali dengan masukan sinusoidal dalam dera putih

Selanjutnya untuk simulasi kondisi friksi statis katup dengan data yang tidak mengalami friksi statis adalah dengan data sinusoidal dan saturasi. Data sinuoidal diketahui tidak friksi statis karena data ini merupakan penyebab buruknya performa 
kalang kontrol. Sedangkan data saturasi diketahui tidak friksi statis katup karena saturasi merupakan penyebab buruknya performa pada katup selain friksi statis katup. Hasil simulasi dengan data tidak friksi statis katup dari metode korelasi silang terdapat pada Tabel 3.

Tabel 3 Hasil deteksi friksi statis katup dengan jenis data tidak friksi statis katup

\begin{tabular}{|l|c|l|l|}
\hline \multirow{2}{*}{ Masukan } & \multicolumn{3}{|c|}{ Korelasi Silang } \\
\cline { 2 - 4 } & $\Delta \rho$ & $\Delta T$ & $\begin{array}{c}\text { Friksi } \\
\text { statis } \\
\text { katup }\end{array}$ \\
\hline Sinusoidal & 0,0322 & 0 & Tidak \\
\hline Saturasi & 0,333 & 0 & Tidak \\
\hline
\end{tabular}

Pada Gambar 7, dan Gambar 8 menunjukkan hasil metode korelasi silang untuk deteksi data tidak friksi statis katup berupa data sinusoidal dan data saturasi.

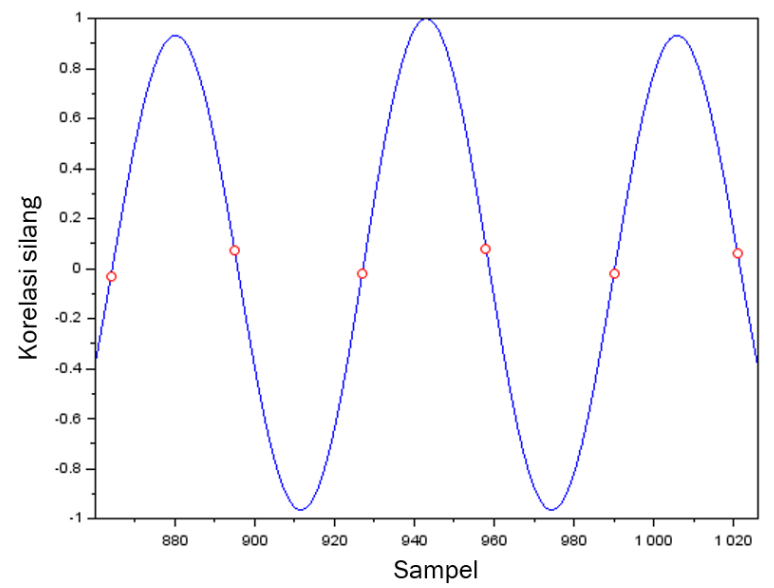

Gambar 7 Hasil metode korelasi silang dengan masukan sinusoidal

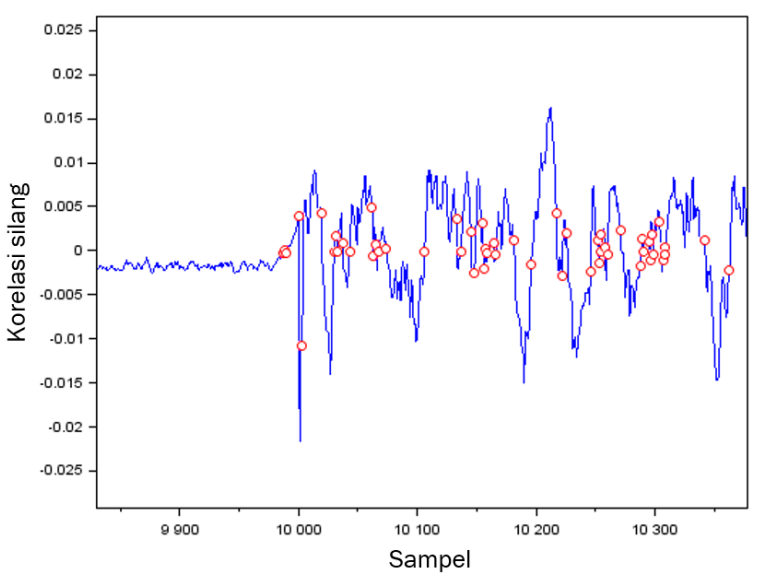

Gambar 8 Hasil metode korelasi silang dengan masukan saturasi
Selanjutnya, data yang digunakan adalah data yang mengalami friksi statis katup. Data friksi statis yang akan dipakai adalah data pemotongan PV dan data simulasi friksi statis katup yang dirumuskan oleh Choudhury. Data pemotongan PV dibuat dengan membuat kurva sinusoidal untuk OP dan PV dengan perbedaan fase. Berikut merupakan algoritma dari data pemotongan PV

Data selanjutnya yang digunakan adalah data friksi statis katup. Data friksi statis katup yang akan dipakai adalah data pemotongan PV dan data simulasi friksi statis katup yang dirumuskan oleh Choudhury. Data pemotongan PV dibuat dengan membuat kurva sinusoidal untuk OP dan PV dengan perbedaan fase, dan memotong beberapa bagian amplitudo puncak dari sinyal PV. Perbedaan fase dalam data ini dimaksudkan sebagai waktu tunda perubahan PV akibat OP. Selanjutnya data PV dipotong pada suatu titik tertentu untuk nilai positif dan negatif., sehingga jika nilai PV melewati batas tertentu, maka nilainya akan tetap hingga melewati titik yang ditentukan. Berikut merupakan diagram alir algoritma dari data pemotongan PV.

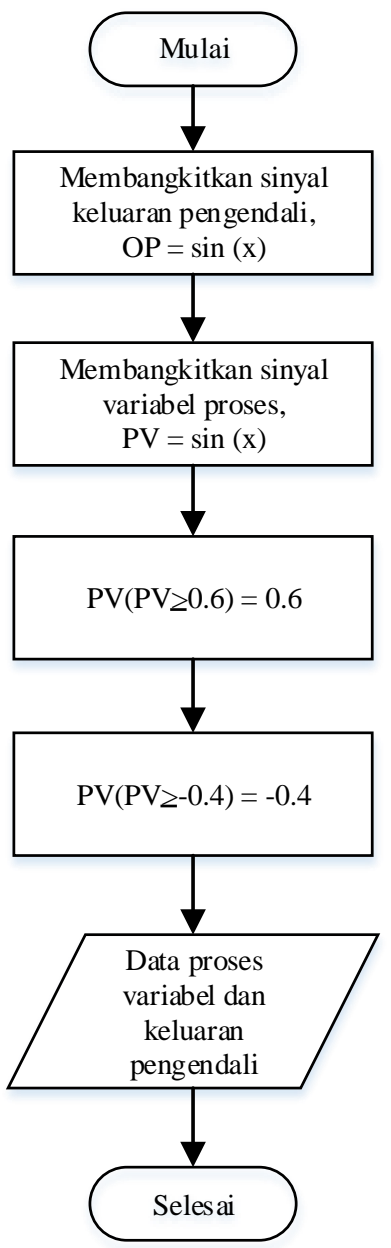

Gambar 9 Diagram alir algoritma data cut PV 
Data simulasi friksi statis katup selanjutnya yang dirumuskan oleh Choudhury [8], memberikan data berupa empat jenis friksi statis katup, yaitu wilayah mati, Ionjakan rendah, tidak ada simpangan, dan Ionjakan tinggi. Tabel 4 menunjukkan hasil dari metode korelasi silang untuk deteksi friksi statis katup dari kelima masukan data friksi statis katup di atas.

Tabel 4. Hasil deteksi friksi statis katup dengan jenis data friksi statis katup

\begin{tabular}{|l|l|l|l|}
\hline \multirow{2}{*}{\multicolumn{1}{c|}{ Masukan }} & \multicolumn{3}{c|}{ Korelasi Silang } \\
\cline { 2 - 4 } & \multicolumn{1}{c|}{$\Delta \rho$} & $\Delta T$ & $\begin{array}{c}\text { Friksi statis } \\
\text { katup }\end{array}$ \\
\hline Pemotongan PV & 0.938 & 0.999 & Ya \\
\hline Wilayah mati & 0.8 & 0.628 & Ya \\
\hline Lonjakan rendah & 0.8 & 0.626 & Ya \\
\hline Tidak ada simpangan & 0.778 & 0.582 & Ya \\
\hline Lonjakan tinggi & 0.75 & 0.53 & Ya \\
\hline
\end{tabular}

Dari tabel tersebut, hasil simulasi menunjukkan hasil yang tepat dalam pendeteksian friksi statis katup untuk semua masukan data friksi statis katup. Semua hasil simulasi dengan data friksi statis katup dan tidak friksi statis katup menunjukkan hasil yang tepat sesuai dengan kondisi masukan data itu sendiri. Hal ini menunjukkan bahwa metode korelasi silang tepat untuk mendeteksi friksi statis katup. Gambar 10 hingga Gambar 14 menunjukkan bagaimana hasil korelasi silang menunjukkan data yang diindikasikan friksi statis katup dengan masukan empat jenis data simulasi friksi statis katup. Hal ini bisa diketahui dengan melihat titik temu nol pertama sebelum dan sesudah titik tengah hasil korelasi silang.

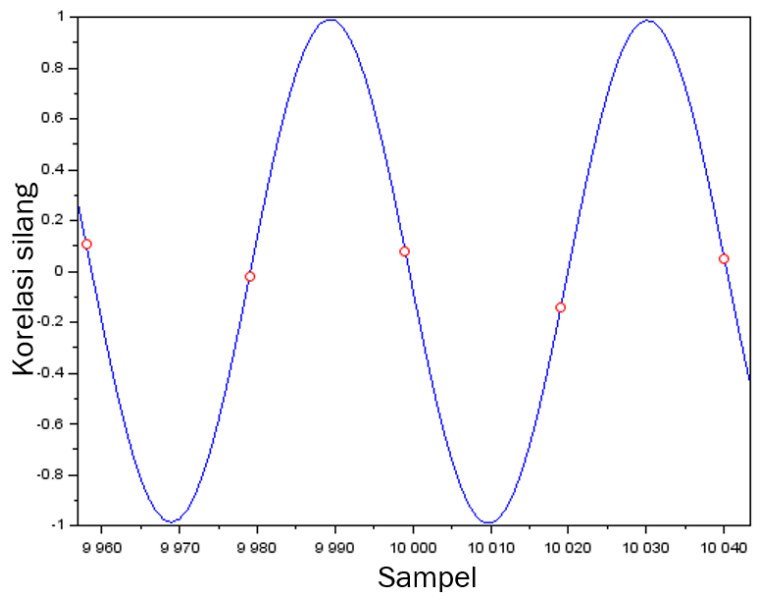

Gambar 10 Hasil metode korelasi silang dengan masukan wilayah mati

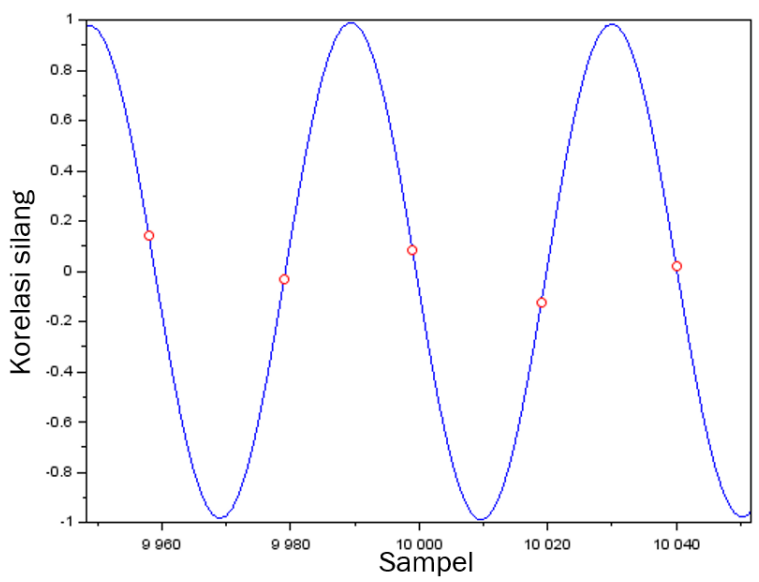

Gambar 11 Hasil metode korelasi silang dengan masukan lonjakan rendah

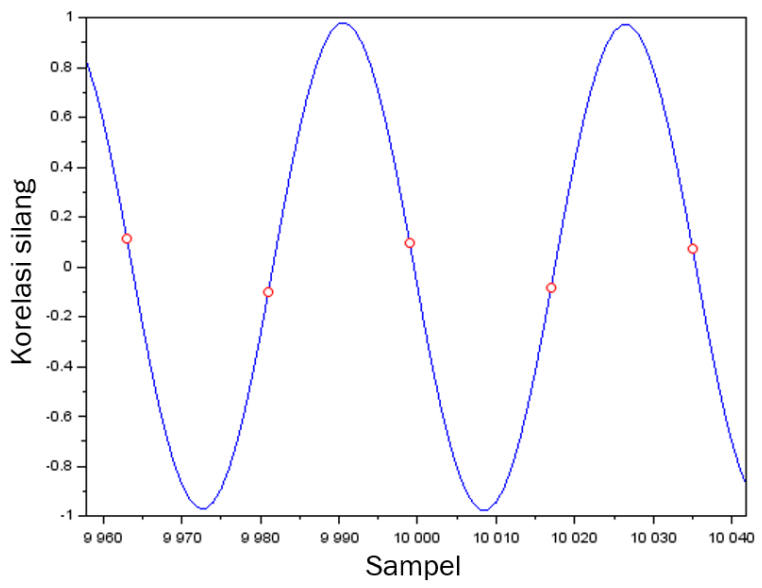

Gambar 12 Hasil metode korelasi silang dengan masukan tidak ada simpangan

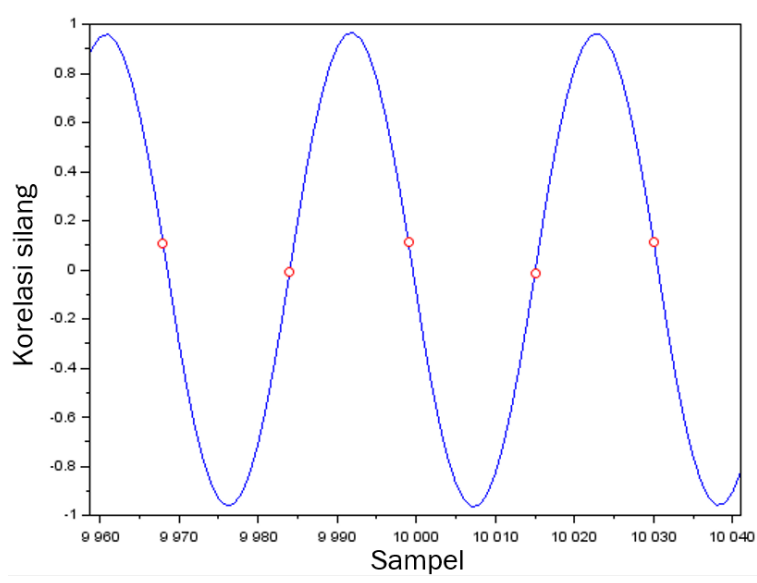

Gambar 13 Hasil metode korelasi silang dengan masukan lonjakan tinggi 


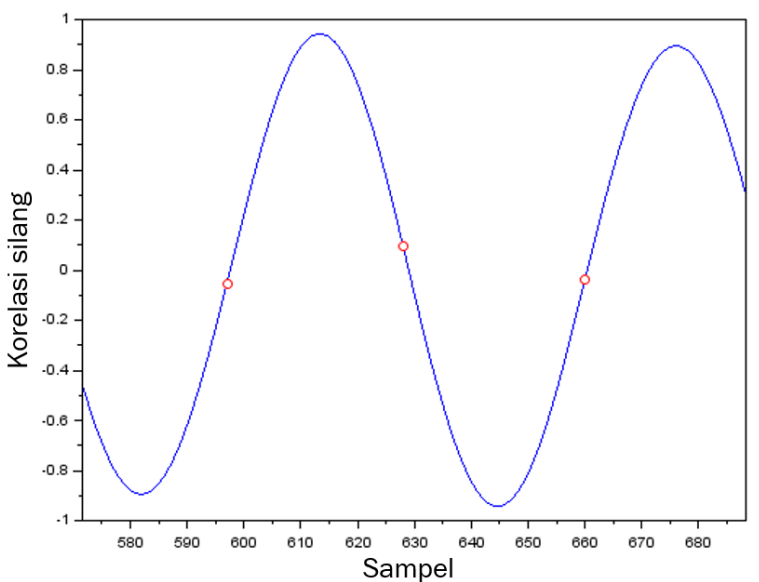

Gambar 14 Hasil metode korelasi silang dengan masukan pemotongan $\mathrm{PV}$

Selanjutnya adalah implementasi pada data industri. Data industri yang dipakai adalah data dari salah satu pabrik amonia

Sebelum masuk pada tahapan deteksi friksi statis pada katup, data dari industri amonia terlebih dahulu diseleksi dengan indikasi osilasi. Untuk mengindikasikan osilasi dilakukan deteksi osilasi dengan menggunakan algoritma integral absolut kesalahan pengendali. Seperti pada paparan sebelumnya untuk mengindikasi osilasi digunakan data PV sebagai masukan untuk deteksi osilasi sehingga didapatkan sinyal kesalahan pengendali. Setelah sinyal kesalahan pengendali diolah dengan menggunakan algoritma ini makan didapatkan nilai indeks osilasi untuk indikasi osilasi.

Jika data tersebut memiliki nilai indeks osilasi lebih dari 0.4, maka data tersebut diindikasikan osilasi. Selanjutnya data yang diindikasikan osilasi akan dilanjutkan dengan deteksi friksi statis katup. Deteksi friksi statis katup dilakukan karena friksi statis katup merupakan salah satu parameter yang mengakibatkan kalang kontrol osilasi. Deteksi friksi statis dilakukan dengan menggunakan metode korelasi silang di mana teknik ini dilakukan dengan mengkorelasisilangkan antara data PV dan data OP. Setelah dilakukan teknik korelasi silang didapatkan beberapa variabel yang digunakan sebagai indikasi friksi statis pada katup, antara lain $\Delta \tau$ dan $\Delta \rho$.

Sementara itu, pada kasus nilai indeks osilasi tidak lebih dari 0.4, maka deteksi friksi statis tidak akan dilakukan. Tabel 5 menunjukkan hasil implementasi metode korelasi silang untuk deteksi friksi statis katup pada data industri amonia.
Tabel 5 Hasil deteksi friksi statis katup dengan data industri

\begin{tabular}{|c|c|c|c|c|c|c|}
\hline Katup & $h(N)$ & Osilasi & $\Delta \mathrm{T}$ & $\Delta \rho$ & KS & K \\
\hline FV1 & 0.466 & $Y$ & 1 & 0.534 & $Y$ & $S$ \\
\hline FV2 & 0.157 & $\mathrm{~N}$ & & & & NO \\
\hline FV3 & 0.285 & $\mathrm{~N}$ & & & & NO \\
\hline FV4 & 0.287 & $\mathrm{~N}$ & & & & NO \\
\hline FV5 & 0.167 & $\mathrm{~N}$ & & & & NO \\
\hline FV6 & 0.433 & $Y$ & 0.777 & 0.523 & $Y$ & $S$ \\
\hline FV7 & 0.25 & $\mathrm{~N}$ & & & & NO \\
\hline FV8 & 0.1 & $\mathrm{~N}$ & & & & NO \\
\hline FV9 & 0.286 & $\mathrm{~N}$ & & & & NO \\
\hline LV1 & 0.22 & $\mathrm{~N}$ & & & & NO \\
\hline LV2 & 0.22 & $\mathrm{~N}$ & & & & NO \\
\hline LV3 & 0.396 & $\mathrm{~N}$ & & & & NO \\
\hline LV4 & 0.72 & $Y$ & 0.939 & 0.774 & $Y$ & $S$ \\
\hline LV5 & 0.479 & $Y$ & 0.956 & 0.375 & $Y$ & $S$ \\
\hline LV6 & 0.43 & $Y$ & 0.692 & 0.419 & $\mathrm{Y}$ & $S$ \\
\hline LV7 & 0.306 & $\mathrm{~N}$ & & & & NO \\
\hline LV8 & 0.284 & $\mathrm{~N}$ & & & & NO \\
\hline LV9 & 0.55 & $\mathrm{~N}$ & 0.428 & 0.222 & ND & ND \\
\hline LV10 & 0.286 & $\mathrm{~N}$ & & & & NO \\
\hline LV11 & 0.297 & $\mathrm{~N}$ & & & & NO \\
\hline PV1 & 0.367 & $\mathrm{~N}$ & & & & NO \\
\hline PV2 & 0.196 & $\mathrm{~N}$ & & & & NO \\
\hline PV3 & 0.232 & $\mathrm{~N}$ & & & & NO \\
\hline PV4 & 0.479 & $Y$ & 0.956 & 0.375 & $Y$ & $S$ \\
\hline PV5 & 0.367 & $\mathrm{~N}$ & & & & NO \\
\hline PV6 & 0.296 & $\mathrm{~N}$ & & & & NO \\
\hline PV7 & 0.465 & $Y$ & 0.846 & 0.436 & $Y$ & $S$ \\
\hline PV8 & 0.656 & $Y$ & 0.846 & 0.655 & $Y$ & $S$ \\
\hline PV9 & 0.154 & $N$ & & & & NO \\
\hline PV10 & 0.583 & $Y$ & 0.753 & 0.366 & $Y$ & $S$ \\
\hline PV11 & 0.295 & $\mathrm{~N}$ & & & & NO \\
\hline PV12 & 0.25 & $\mathrm{~N}$ & & & & NO \\
\hline
\end{tabular}

Keterangan:

$h(N)=$ Indeks Osilasi

$\Delta \mathrm{T}=$ Variabel pertama indeks friksi statis katup

$\Delta \rho=$ Variabel kedua indeks friksi statis katup

$\mathrm{KS}=$ Korelasi silang

$\mathrm{K}=$ Kesimpulan Akhir

$\mathrm{S}=$ Hasil yang menunjukkan friksi statis katup

$\mathrm{NO}=$ Hasil yang menunjukkan tidak osilasi

ND = Hasil yang menunjukkan tidak ada keputusan 
Hasil pada Tabel 5 menunjukkan bahwa hasil deteksi friksi statis katup dengan menggunakan metode korelasi silang menghasilkan 10 katup yang diindikasikan osilasi. Di antara 10 katup tersebut, 9 katup diindikasikan friksi statis katup, dan katup lainnya diindikasikan dalam kondisi tidak ada keputusan. Menurut Horch, kondisi katup yang berada pada kondisi tidak ada keputusan dapat diakibatkan oleh kesalahan sensor, atau elemen lain yang berkaitan dengan katup [5]. Tabel 5 menunjukkan kesimpulan hasil dari implementasi data industri.

Tabel 5 Kesimpulan hasil deteksi friksi statis katup dengan data industri

\begin{tabular}{|l|l|}
\hline \multicolumn{1}{|c|}{$\begin{array}{c}\text { Kesimpulan } \\
\text { Kondisi Katup }\end{array}$} & Jumlah \\
\hline Osilasi & 10 \\
\hline Friksi statis katup & 9 \\
\hline $\begin{array}{l}\text { Tidak ada } \\
\text { keputusan }\end{array}$ & 1 \\
\hline
\end{tabular}

Selain memberikan hasil yang tepat pada hasil simulasi, kelebihan lain yang dimiliki metode korelasi silang adalah kemudahan dalam implementasiannya. Di mana untuk dapat mengetahui suatu kondisi katup mengalami friksi statis katup atau tidak friksi statis katup, bisa didapatkan dari keempat variabel dari hasil korelasi silang, yaitu $\tau_{1}, \tau_{r}, r_{o p t}$, dan $r_{0}$. Gambar 15 menunjukkan bagaimana mendapatkan keempat variabel yang digunakan untuk indikasi friksi statis pada katup LV4.

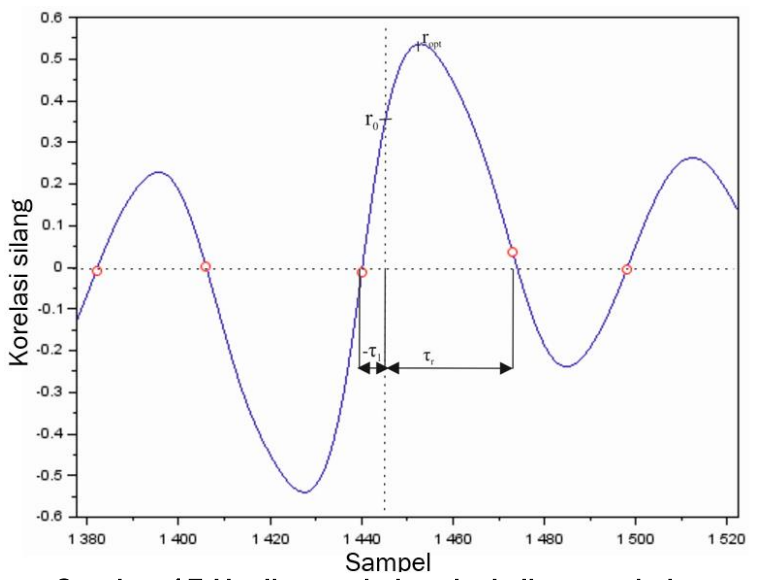

Gambar 15 Hasil metode korelasi silang pada katup LV4

\section{Kesimpulan}

Dari hasil implementasi yang dilakukan pada deteksi friksi statis katup dengan menggunakan metode korelasi silang, didapatkan karakteristik dari metode tersebut. Implementasi metode korelasi silang untuk deteksi friksi statis katup dilakukan dengan beberapa data simulasi dan data industri amonia.

Dari hasil simulasi, menunjukkan bahwa metode korelasi dapat memberikan hasil yang tepat dalam pendeteksian friksi statis pada katup. Hasil ditunjukkan pada data simulasi yang diindikasikan friksi statis terbaca dengan benar dalam keadaan friksi statis dengan metode korelasi silang. Begitu juga dengan data simulasi yang tidak mengalami friksi statis. Hasilnya juga menunjukkan indikasi tidak friksi statis. Dengan demikian, pada data simulasi disimpulkan bahwa metode korelasi silang dapat memberikan hasil yang tepat 100\% dalam pendeteksian friksi statis pada katup.

Sementara itu, dari hasil implementasi pada data industri didapatkan hasil implementasi deteksi friksi statis pada katup mengindikasikan 31,25\% dari 33 kalang kontrol pada industri amonia mengalami osilasi dengan rincian 28,125\% terindikasi friksi statis pada katup, sedangkan sisanya $3,12 \%$ osilasi terjadi bukan karena friksi statis pada katup.

\section{Daftar Pustaka}

[1] Forsman, K., \& Stattin, A (1999). A new criterion for detecting oscillations in control loops. European Control conference, Karlsruhe, Germany, CP8-3.

[2] Horch, A. (1999). A simple method for detection of stiction in control valves. Control Engineering Practice, 7(10), 1221-1231.

[3] Horch, A. (2000). Condition Monitoring Loops. PhD thesis, Royal Institute of Technology, Stockholm, Sweden.

[4] Jelali, , M., \& Huang, B. (Eds.), Detection and diagnosis of stiction in control loops: state of the art and advanced methods. London: Springer Science \& Business Media, 2009.

[5] Widjayanto, M.A.R. "Penerapan Metode Korelasi Silang Untuk Deteksi Stiction pada Katup Kontrol," Skripsi, Universitas Gadjah Mada, 2015.

[6] Shoukat-Choudhury, S. M. A. A., Shah, S. L., \& Thornhill, N. F, Diagnosis of Process Nonlinearities and Valve Stiction, London: Springer Science \& Business Media, 2008 